UDK: $341.63: 339.5$

CERIF: S 144

ТИП РАДА: ПРЕГЛЕДНИ НАУЧНИ РАД

DOI: $10.5937 / \mathrm{PiP} 2101052 \mathrm{~S}$

Baľ̌a STEVANOVIĆ, BSc, LL.M, M.A*

Junior Lawyer, Tomić Sinđelić Groza Law Office, Belgrade, Republic of Serbia

\title{
INTERNATIONAL COMMERCIAL COURTS AS NEW ACTORS IN ADJUDICATION BUSINESS: COLLABORATORS OR COMPETITORS? ${ }^{* *}$
}

\begin{abstract}
Summary
International commercial courts are a relatively new phenomenon that changes the configuration of the international adjudication business. As novel players on the dispute resolution scene, these courts challenge the notion of competition between the existing actors in the business. From the perspective of arbitration, international commercial courts tend to be perceived as both collaborators and competitors. Furthermore, various driving forces influenced the creation of these courts, which gave them a hybrid structure and a quite unique institutional appearance. This article examines three prominent courts in three different parts of the world: the Dubai International Financial Centre Courts (DIFCC), the Singapore International Commercial Court (SICC) and the Netherlands Commercial Court (NCC). The aim is to identify the main features of these adjudication actors that operate within three highly commercially relevant geographic regions in order to outline their character and role on the

* e-mail: balsa.stevanovic@tsg.rs.

** I undertook research for this article during exchange semester I spent at the Boston University School of Law. Many thanks to Professor Virginia Greiman for guidance and help.
\end{abstract}


adjudication business stage. Eventually, through these examples this article addresses the puzzling question of competition versus cooperation in contrast to arbitration. Nevertheless, it is still hard to give a definitive answer - it seems too early for a firm prediction regarding the future of these projects. Jurisprudence must be developed in order to comprehensively test the success of international commercial courts.

\section{Key words: Dispute Resolution. - International Commerce. - International Commercial Arbitration. - International Commercial Courts. - Transnational Litigation.}

\section{Introduction}

International commercial courts can be defined as state-established, English-language-friendly domestic courts specializing in international commercial disputes. ${ }^{1}$ Since 2004, these courts have appeared in Dubai, Qatar, Singapore, Abu Dhabi, Kazakhstan and China, with several European countries following this trend by establishing or planning to establish courts of this type (Germany, France, the Netherlands, Belgium and Switzerland). ${ }^{2}$ The establishment of these new players changes the configuration of the global adjudication scene and challenges the existing notion of competition between the actors in the business. International commercial courts are not international stricto sensu, but rather domestic courts with a widely established jurisdiction to deal with international commercial matters. These courts had been primarily established to complement states' existing offer to resolve disputes by adding yet another litigation option. Options of the latter kind are commonly advertised as innovative and cost-effective, while in reality they are hybrid of litigation and arbitration. ${ }^{3}$ This article tends to illuminate the dispute resolution business (Part 2) and the process of the creation of international commercial courts (Part 3). These general insights are combined with the features of international commercial courts through three prominent examples (Dubai, Singapore, the Netherlands) that are chosen as representatives of three important international business regions (Part 4). The final step is to determine whether these new courts are partners or competitors to the existing dispute resolution mechanisms, predominantly compared to arbitration (Part 5), followed by the concluding remarks (Part 6).

1 Pamela K. Bookman, “The Adjudication Business", The Yale Journal of International Law, Nr. 45/2020, 228.

2 Ibid.

3 Ibid., 229. 


\section{Dispute Resolution Business}

The international adjudication business could be defined as the resolution of international commercial disputes through domestic courts (global - transnational litigation), or through various forms of alternative dispute resolution (ADR), including arbitration. As underlined, this setting has been recently supplemented with new actors on the stage.

\section{Global Litigation and International Commercial Arbitration}

According to Slaughter ${ }^{4}$ and Dubinsky, ${ }^{5}$ the global economy creates global litigation. As both production and distribution are dispersed worldwide, the rough battle over jurisdiction and the choice of forum seems to be the same as the battle over the merits of the case. Nowadays, practicing lawyers are faced with an increased number of disputes that include foreign litigants, foreign law, or the interests of foreign countries. These foreign elements all brought remarkable novelties compared to ordinary domestic litigation: from a distinct substantive body of law to new strategic considerations to have in mind. ${ }^{6}$ Consequently, this global environment fueled the growth of international commercial arbitration, ${ }^{7}$ alongside other forms of alternative dispute resolution (ADR). As lawyers increasingly specialize in disputes that cross national borders, they turn to 'an elite group of party-chosen arbitrators' in serving clients' interests. ${ }^{8}$

Broadly speaking, transnational arbitration is a mechanism of dispute resolution by a third party (arbitrator) who resolves a dispute pursuant to the agreement between the parties to submit their dispute to arbitration. Furthermore, it is private contracting that most visibly created demand for third-party dispute resolution. ${ }^{9}$ This form of transnational contracting makes international arbitration part of transnational private governance, which inevitably facilitates the wider process of global governance. ${ }^{10}$ For a fairly long time, arbitration has been considered one of the main mechanisms to resolve

4 Anne-Marie Slaughter, A new world order, Princeton, 2004, 85; Anne-Marie Slaughter, "Judicial globalization", Virginia Journal of International Law, Nr. 40/1999, 1112.

5 Paul R. Dubinsky, "Is International Litigation a Field? Two Views of the Border", Proceedings of the ASIL Annual Meeting, Vol. 101, 2007, 366.

$6 \quad$ Ibid., 365.

7 A. M. Slaughter (2004), 85; Anne-Marie Slaughter, "A global community of courts", Harvard International Law Journal, Nr. 44/2003, 204.

$8 \quad$ P. R. Dubinsky, 366.

9 Christopher A. Whytock, "Domestic courts and global governance", Tulane Law Review, Nr. 84/2009, 111.

10 Ibid. 
international commercial disputes. Nevertheless, a significant number of new players - international commercial courts - entered the dispute resolution scene recently alongside those in arbitration and transnational litigation. With their rapid diffusion in several jurisdictions, these courts represent the next frontier in international economic law and relations. ${ }^{11}$

Appreciating that international commercial arbitration is the dominant alternative to the court system, the main features favored by its users are its predictability, lower costs, arbitrators' expertise, privacy and confidentiality, and easy enforcement through the almost universal system of the New York Convention. According to International Arbitration Survey, ${ }^{12}$ the arbitration community would almost unanimously (99\%) recommend arbitration to resolve cross-border disputes in future. Furthermore, the community considers the ease of enforcing awards as arbitration's most valued characteristic, followed by 'avoiding specific legal systems/national courts', 'flexibility' and 'ability of parties to select arbitrators. ${ }^{13}$

Therefore, international commercial arbitration represents a true victory of party autonomy - parties are free to tailor the dispute resolution mechanism such that suits their interests best. Moreover, given the present proliferation of various highly reputable arbitral seats ${ }^{14}$ and arbitral institutions, parties can also be sure that their cases will be well administered. All the above stated suggests that arbitration tends to be a satisfactory mechanism to resolve international commercial disputes. Nevertheless, the survey shows that the arbitration's worst feature is its cost, followed by 'lack of effective sanctions during the arbitral process', 'lack of power in relation to third parties' and 'lack of speed.'

Despite the resounding praise of arbitration, these negative features may be seen as the main impetus for the creation of international commercial courts, according to Demeter and Smith. ${ }^{16}$ In addition, as stressed by

11 Lance Ang, International Commercial Courts and the Interplay Between Realism and Institutionalism: A Look at China and Singapore (Essay, Online Scholarship), Harvard International Law Journal, 2019, available at: https://harvardilj.org/2020/03/internationalcommercial-courts-and-the-interplay-between-realism-and-institutionalism-a-look-atchina-and-singapore/, 27. 12. 2020.

12 University of London, Queen Mary School of International Arbitration, 2018 International Arbitration Survey: The Evolution of International Arbitration, 2018, available at: http:// www.arbitration.qmul.ac.uk/research/2018/, 20. 12. 2020, 5.

13 Ibid., 5-7.

14 Based on the general reputation and recognition, the most popular arbitral seats are London, Paris, Singapore, Hong Kong and Geneva. Ibid., 9.

15 Ibid., 5.

16 Dalma R. Demeter, Kayleigh M. Smith, "The Implications of International Commercial Courts on Arbitration", Journal of International Arbitration, Nr. 5/2016. 
Ramesh, ${ }^{17}$ international commercial courts are, inter alia, addressing arbitration's market failure. Yet in 2018, the international business community was still quite determined to use arbitration as the default mechanism to resolve cross-border disputes. This sustained and intense pro-arbitration attitude may be related to the fact that these new international commercial courts are established within the official states' domestic judicial apparatus. Typical restraints of the domestic system are found in the lack of party control over the choice of adjudicators and lawyers who can represent parties before these courts. In that sense, the interest of states and businesses to have international commercial courts as another dispute resolution mechanism may not at all be in the interest of legal counsel and international arbitrators who may see these recent developments as limiting their options. Having that in mind, there is a whole distinct domain to research on the role of lawyers as 'forces for legal and institutional change.. ${ }^{18}$

\section{The Rise of International Commercial Courts}

International commercial courts challenge the existing transnational litigation environment through hybridization, internationalization and party autonomy. ${ }^{19}$ Even though this is outlined as a feature of the Singapore Commercial Court, it can be expanded as a general stance: these courts coopt a public-private perspective to the resolution of international commercial disputes. ${ }^{20}$ More specifically, they bring in a public interest element into the international dispute resolution, while at the same time they introduce selfdetermination (party autonomy) to international commercial litigation. ${ }^{21}$ Furthermore, it is observed by Chong that international commercial courts are 'a careful marriage between litigation and arbitration.' 22 That is the reason why Demeter and Smith consider all these alternatives to arbitration as a

17 Kannan Ramesh, "International Commercial Courts: Unicorns on a Journey of a Thousand Miles", Conference on the Rise of International Commercial Courts, 2018, available at: https://www.sicc.gov.sg/docs/default-source/modules-document/news-and-article/inter national-commercial-courts-unicorns_23108490-e290-422f-9da8-1e0d1e59ace5.pdf, 11. 12. 2020.

18 P. Bookman, 283

19 Man Yip, “The Singapore International Commercial Court: The Future of Litigation”, Erasmus Law Review, Nr. 12/2019, 82.

20 Ibid.

21 Ibid.

22 Steven Chong, "The Singapore International Commercial Court: A New Opening in a Forked Path", British Maritime Law Association Lecture and Dinner in London, 2015, available at: https://www.supremecourt.gov.sg/Data/Editor/Documents/J\%20Steven\%20 Chong\%20Speeches/The\%20SICC\%20-\%20A\%20New\%20Opening\%20in\%20a\%20 Forked\%20Parth\%20-\%20London\%20(21.10.15).pdf, 11. 12. 2020, para. 52. 
hybrid; it is not quite akin to arbitration, but it cannot be equated to ordinary litigation before a national court. ${ }^{23}$

These new developments influenced the arbitration environment in various ways. First, one can instantly conclude that a choice of proper dispute resolution mechanism is nowadays more than just a champagne clause triviality of the past. For both global businesses and legal communities, it is remarkably important to be aware of the existence and features of the new mechanisms on the dispute resolution scene in order to better understand these projects and properly evaluate their (dis)advantages. At this point, at least one observation is clear: these new courts are fascinating developments in world business judiciaries and the analysis of the phenomenon touches upon procedural innovation, legal institution-building, transnational governance, the role of courts in establishing and maintaining the rule of law and beyond. ${ }^{24}$

\section{International Commercial Courts}

The increasing proliferation of English-speaking courts dealing with international commercial matters is visible through Europe, Asia and the Middle East. ${ }^{25}$ Prominent examples include the Dubai International Financial Centre Courts (DIFC Courts), the Singapore International Commercial Court (SICC), the China International Commercial Courts (CICCs), the Netherlands Commercial Court (NCC), the International Chamber of the Paris Commercial Court and the International Chamber for Commercial Disputes of the Frankfurt Regional Court. ${ }^{26}$ Furthermore, Belgium plans to establish the Brussels International Business Court (BIBC). ${ }^{27}$ The literature and research on this topic go into several directions. The first part of the available work deals with 'technical' characteristics of these courts as a new phenomenon, their legal nature, the character of decisions and the influence on the arbitration. The second part of the scholarship is focused on particular case studies. Finally, there is a body of work that tries to adopt a wider perspective in explaining the forces that created these courts, the main interests involved as well as the legal and societal consequences of these developments.

23 D. R. Demeter, K. M. Smith, 442.

24 Pamela Bookman, "New Courts, New Perspectives", Jotwell: The Journal of Things We Like (Lots), 2019, available at: https://courtslaw.jotwell.com/new-courts-new-perspectives/, 20. 12. 2020, 1.

25 Dorothee Ruckteschler, Tanja Stooss, "International Commercial Courts: A Superior Alternative to Arbitration?”, Journal of International Arbitration, Nr. 4/2019, 431.

26 Ibid.

27 Ibid. 
In the manner of the first part of literature, Ruckteschler and Stooss define international commercial courts as specialized (state) courts established by national legislators. ${ }^{28}$ Furthermore, in analyzing the motivating factors that triggered legislators to take this step, they found that some of the courts (including the Chinese CICC) were established to facilitate and promote specific projects, such as the Belt and Road Initiative. ${ }^{29}$ There are examples proving that some of these courts are established as a need for general promotion of the adjudication business. Accordingly, the Singapore International Commercial Court is a result of the plan to promote Singapore as the regional hub for cross-border dispute resolution, while the Amsterdam Court (alongside other European projects) is a direct response to Brexit, which revealed the potential to effectively replace London as a traditionally dominant center for adjudication of international commercial disputes. ${ }^{30}$ One of the commonly stressed comparative advantages of these European courts is the fact that they operate within highly stable legal systems in the European Union Member States. Moreover, these courts are receptive to the English language as the procedural language, and the applicable laws before them offer fair and predictable solutions tailored to business needs. On the other hand, the SICC and DIFC Courts tend to focus their services on the parties who found arbitration unsatisfactory for their needs. ${ }^{31}$

Needless to say, the factors that influenced the process of creation of international commercial courts are multidimensional and rather complex. For this reason, Bookman offers a wider analysis of the adjudication business as a whole. ${ }^{32}$ Namely, Bookman outlines that traditional accounts of the competitive relationship between and among courts and arbitral tribunals produce three narratives. The first narrative posits that competition is a positive force that represents a race to the top for the most efficient dispute resolution. The second presents arbitration and litigation as two quite different alternatives. The final narrative asserts that parties prefer arbitration to resolve disputes arising from international commercial contracts. ${ }^{33}$ Eventually, it is argued that the recent proliferation of international commercial courts challenges all three assumptions. Jurisdictions where international commercial courts are established in fact embrace litigation and at the same time make their laws favorable for arbitration. ${ }^{34}$

28 Ibid., 432.

29 Ibid.

$30 \quad$ Ibid., 433.

31 D. R. Demeter, K. M. Smith, 444.

32 P. Bookman (2020).

33 Ibid., 230-232.

34 Ibid., 229. 
Since there are different potential reasons why international commercial courts emerged, Bookman concludes that success of these courts is to be measured based on what initially led to their creation. ${ }^{35}$ According to Bookman, these courts can be divided into four groups. The first group encompasses 'old school' international commercial courts, namely London and New York. The second group consists of investment-minded courts, such as Qatar and Dubai. The third group comprises aspiring litigation destinations such as Singapore. The fourth group is recognized as the 'Courts on the Continent' (Amsterdam, Paris, Frankfurt, and Brussels). Notwithstanding, one court does not subscribe to any of the four groups, that is, the Chinese International Commercial Court. It aims to become a one-stop-shop for all international commercial dispute resolution related to the Belt and Road Initiative, thus having a 'unique potential for global influence.36

As a great addition to Bookman's setting of the stage comes Erie's work on New Legal Hubs. ${ }^{37}$ This is the analysis of 'one-stop-shops' for cross-border dispute resolution, created in financial centers by non-democratic or hybrid regimes. ${ }^{38}$ These hubs are created in order to address the legitimacy deficit of host states and insufficient economic growth. ${ }^{39}$ The theory of new legal hubs (NLHs) is based on the intraregional dynamics, while legal hubs are seen as the catalyst of globalization. However, these hubs become particularly relevant in the period of globalization's slowdown. ${ }^{40}$ Therefore, NLHs are modern multi-door courthouses for sophisticated legal disputes that offer equally sophisticated and diversified resolution mechanisms. ${ }^{41}$ These hubs are mini-engines of globalization and as such, they can never fully eclipse the state politics of the host states. ${ }^{42}$ Erie uses the well-known examples of Singapore and Dubai, but also adds Hong Kong, Shanghai, Shenzhen and Astana to the debate. One of the main processes with regards to these NLHs

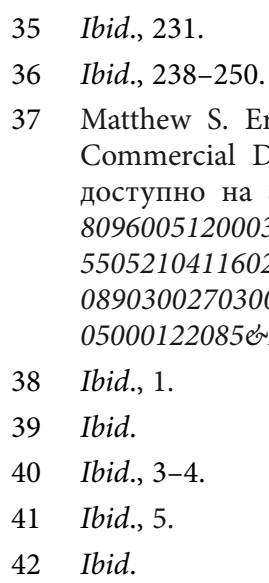

38 Ibid., 1.

39 Ibid.

40 Ibid., 3-4.

41 Ibid., 5.

42 Ibid.

37 Matthew S. Erie, "The New Legal Hubs: The Emergent Landscape of International Commercial Dispute Resolution", Virginia Journal of International Law, Nr. 3/2019, доступно на адреси: https://poseidon01.ssrn.com/delivery.php?ID=50507408211409601 80960051200031110290490470560840300891240650940091230711270980700020521030 55052104116023097117126007076081099028045036041065016029098016005025024071 0890300270300801250900990950760950921150681180250670120250701161180971181 05000122085\&EXT=pdf\&INDEX=TRUE, 20. 12. 2020, 1-61. 
is 'facilitation of the cross-border transactions by anchoring transnational law through optimization of conflict of laws rules at the local level. ${ }^{43}$

\section{The Main Features of the Prominent International Commercial Courts - Dubai, Singapore, and the Netherlands}

In order to determine the implications of the establishment of international commercial courts for arbitration as a current hallmark mechanism for the resolution of international commercial disputes, we should turn to the analysis of the main features of three prominent international commercial courts. Namely, we will present the Dubai International Financial Centre Courts (DIFC Courts), the Singapore International Commercial Court (SICC) and the Netherlands Commercial Court (NCC).

\section{Dubai International Financial Centre Courts (DIFCC)}

According to Dubai International Financial Centre Courts' Work Plan (2020-2021), Emirate of Dubai made a daring move over a decade ago by establishing DIFC free zone with common law structures and governance in an otherwise typical civil law environment. This new judicial system is an integral part of the UAE's commitment to provide a competitive business environment. The UAE's investment in technology paved the way for the establishment of one of the most successful English-speaking courts in the world. Future-wise, DIFC Courts' plans are focused on judicial excellence, service excellence, innovation, and connectivity. DIFC Courts are also described as 'a common law island in a civil law ocean. ${ }^{44}$ As stated, while the UAE laws are based on civil law, the governing law of the DIFC Courts is specifically tailored and based on common law. This means that the operating legal system is based on English law in codified form, with civil law influences. ${ }^{4}$

The DIFCC Arbitration Law is specifically based on the UNCITRAL Model Law, applicable to all the arbitral proceedings seated in the DIFC. Moreover, it is important to note that DIFC is a different seat from the Emirate of Dubai. ${ }^{46}$ As a matter of jurisdiction, DIFC Courts can hear cases

\footnotetext{
43 Ibid., 57.

44 Michael Hwang, "Commercial courts and international arbitration - competitors or partners?", Arbitration International, Nr. 2/2015, 201.

45 Ibid., 202.

46 Ibid.
} 
related to the parties incorporated or registered in the DIFC or cases related to an occurrence within the DIFC. Additionally, since 2011 there is the optin jurisdiction to hear cases from around the globe, subject of a written jurisdiction agreement. ${ }^{47}$ One of the most important questions in relation to international commercial courts generally is the enforceability of judgments. Namely, with the widely applicable mechanism of the New York Convention - a widely ratified treaty that prescribes judicial recognition and enforcement of arbitration agreements and arbitral awards - arbitration has a strong advantage on the global stage. ${ }^{48}$ Contrary to the recognition and enforcement of foreign judgments, there is more deference in the case of foreign arbitral awards. The court is only searching for procedural irregularities and allows non-enforcement if arbitral awards conflicts with local public policy. ${ }^{49}$

Since the exceptions are narrowly construed, there is a sort of presumption by disputants that domestic courts of participating states are generally ready to recognize and enforce foreign arbitral awards. This creates, even before the recognition and enforcement procedure, an additional guarantee of judicial support to international arbitration. ${ }^{50}$ On the occasion of 20 years of the New York Convention's existence, many authors commented that the 1958 ratification was a considerable success for an international convention on private law, ${ }^{51}$ which offered clear advantages compared to the situation before it came into force. ${ }^{52}$

State parties to the Convention comprise both developed and developing nations from the East and the West and include all major trading players. ${ }^{53}$ Nevertheless, such universal enforceability of the court judgments is yet (if ever) to be achieved. In the DIFC Courts' case, the big advantage is the fact that judgments are registrable in the state courts of mainland Dubai without any challenge to the substance of the judgment. ${ }^{54}$ This means that all the mechanisms available to Dubai state courts' judgments to be enforced worldwide are likewise available to the DIFC Courts' judgments. The second possibility is related to the highly debated project of the 'conversion' of

$47 \quad$ Ibid.

48 Convention on the Recognition and Enforcement of Foreign Arbitral Awards, New York, 10 June 1958.

49 Paul B. Stephan, "Courts on Courts: Contracting for Engagement and Indifference in International Judicial Encounters", Virginia Law Review, Nr. 100/2014, 82.

50 C. A. Whytock, 113.

51 Jenny S. Martinez, “Towards an international judicial system”, Stanford Law Review, Nr. 56/2003, 441.

52 Pieter Sanders, "A Twenty Years' Review of the Convention on the Recognition and Enforcement of Foreign Arbitral Awards", International Lawyer, Nr. 13/1979, 269.

53 Ibid.

54 M. Hwang, 203. 
court judgments into arbitral awards. ${ }^{55}$ Briefly, it is not a conversion stricto sensu - it just enables judgment creditor to have an additional mode of the enforcement of judgment, without losing its rights under that judgment. ${ }^{56}$ Therefore, this will give DIFCC judgments more global reach, by introducing this tool that synthesizes litigation and arbitration by giving concurrent remedies for enforcement. ${ }^{57}$ Nevertheless, the question of the 'conversion' of court judgments into arbitral awards has been described as a creative initiative and an unprecedented construction worldwide. ${ }^{58}$ The initiative will inevitably bring the system of international commercial courts closer to arbitration in terms of enforcement. However, this raises numerous theoretical and practical issues, such as broadening the scope of the New York Convention beyond of that originally intended, the problem of definition of the arbitral awards and disputes. ${ }^{59}$ In terms of the other features of DIFC Courts, the rules of evidence are taken from the International Bar Association Rules on the Taking of Evidence in International Arbitration, while the composition of judges is mixed, comprised both of foreign and Emirati judges. ${ }^{60}$

\section{Singapore International Commercial Court (SICC)}

The SICC is an important regional player in Asia, established in 2015 after the division of Singapore High Court. ${ }^{61}$ This court is part of a wider project of the Singapore state to promote Singapore as the dominant regional hub for international dispute resolution. Indeed, Singapore received recognition for its excellence in dispute resolution services. The SICC had been established in a short period of time, backed by engaged marketing and promotional work alongside the extensive funds given by the government of Singapore. Since its establishment, this court was well received by the international legal community due to the quality of both judges and judgments. ${ }^{62}$ Nevertheless, some critics also underline that the neutrality of Singapore's courts has been questioned, especially in politically sensitive cases. ${ }^{63}$ More broadly, the main reasons for the establishment of the SICC are related to national

55 Ibid., 202.

56 Ibid.

57 Ibid., 211.

58 D. R. Demeter, K. M. Smith, 454.

59 Ibid.

60 P. Bookman (2020), 243.

61 Ibid., 247.

62 John Middleton, "The Rise of the International Commercial Court", The 2018 Hong Kong International Commercial Law Conference, 2018, available at: https://www.fedcourt.gov.au/ digital-law-library/judges-speeches/justice-middleton/middleton-j-20180921, 27. 12. 2020.

63 P. Bookman (2020), 249. 
interests, regional needs and public interest (to provide a coherent and transparent development of commercial law). ${ }^{64}$ As far as jurisdiction of the SICC is concerned, it is established with an agreement between parties to refer disputes to the SICC or without such an agreement in cases filed in the Singapore High Court that the High Court determines to come under the jurisdiction of the SICC. ${ }^{65}$ In that sense, the observation of Chief Justice Menon is indicative - the SICC is envisaged as a forum dedicated to the resolution of only international commercial disputes. Opposite to DIFCC, SICC's jurisdiction does not have a significant domestic component. ${ }^{66}$ The SICC procedural framework recognizes a greater scope for the consideration of parties' preferences than the traditional litigation process. ${ }^{67}$ Furthermore, SICC comprises of international judges appointed by the special procedure and treated differently from other Supreme Court judges. ${ }^{68}$ Moreover, the important feature of the SICC litigation is the possibility of party joinder. A party can be joined to an SICC action as an additional plaintiff or defendant or as a third or subsequent party, when the claims by or against the person are 'appropriate' to be heard before the SICC. ${ }^{69}$ Most importantly, this means that SICC can join parties without their consent. Since this procedural aspect would be problematic in arbitral proceedings, the solution within SICC can be seen as a potential comparative advantage of international commercial courts compared to international arbitration. Nevertheless, if a party is not cooperative this may cause problems in the enforcement of these judgments against that party in other jurisdictions. ${ }^{70}$ In terms of the enforcement of SICC judgments, the same obstacle remains as with all the other international commercial courts (apart from the DIFCC and the unusual conversion initiative described above, where a potential success is yet to be evaluated).

Singapore International Commercial Court judgments are enforceable the same way as all the other High Court decisions. In that sense, there is a heavy reliance on the bilateral and multilateral arrangements that are or will be concluded by Singapore. Considering the SICC's main motive of promoting Singapore as a one-stop-shop legal hub in the region, it can be expected that the official state will take all necessary steps to make easier the enforcement of its court's judgments worldwide. So far, Ramesh recognizes

64 M. Yip, 83.

65 M. Hwang, 196. For more detailed analysis on the SICC jurisdiction, see also: M. Yip, $85-88$.

66 D. Ruckteschler, T. Stooss, 433.

67 M. Yip, 88.

68 Andrew Godwin, Ian Ramsay, Miranda Webster, "International commercial courts: The Singapore experience”, Melbourne Journal of International Law, Nr. 2/2017, 224.

69 Ibid., 228.

70 Ibid. 
four different models of the SICC judgments enforcement through: (1) the mechanism of the Hague Convention on the Choice of Courts Agreement; (2) the registration based on the reciprocal agreements; (3) a common law suit, since the SICC judgment creates a debt; or (4) a suit in civil law jurisdictions subject to their particular rules. ${ }^{71}$ Additionally, it is possible that the SICC signs bilateral or multilateral memoranda with other courts to set out the rules on the mutual enforcement in each jurisdiction.

Since international commercial courts are part of formal state apparatus, the representation before these courts by foreign lawyers is generally expected to be more restricted compared to the counsel rules in arbitral proceedings. At best, there is some form of the registration required. For instance, Queen's Counsels or equivalent may be admitted to practice in the Supreme Court of Singapore on an ad hoc basis for a specific case, depending on the various requirements regarding the special qualifications, 'necessity', language requirements and relevant experience. ${ }^{72}$ Obviously this aspect of clients' representation echoes the standard state courts' formalism. As far as the determination of foreign law is concerned, the Singapore court offers a possibility to consider foreign law not solely as a fact to be proven by expert evidence, but it can also be determined on the basis of submissions instead of proof. ${ }^{73}$

\section{Netherlands Commercial Court (NCC)}

Compared to the DIFCC and the SICC, the Netherlands Commercial Court (NCC) is a European example of the project, established within the Dutch legal system that cherishes a long tradition of proficiency in international commerce. Furthermore, the main reasons that triggered its establishment are somewhat different compared to the DIFCC and SICC. Namely, more than establishing a one-stop-shop to attract investments, the NCC was established at the time when Brexit was an evident occurrence. Brexit was perceived as a chance to compete for the international commercial litigation business that was traditionally at the world-famous London Commercial Court. Even though some plans for the establishment of international commercial courts in Europe existed for many years, Brexit undoubtedly increased their priority and urgency. Furthermore, the overall aim of all European international commercial courts is to offer the advantage of litigation on the local soil to domestic companies, through a system that would be more acceptable to foreign partners than national courts. Furthermore, regarding the NCC example, the Dutch civil jurisdiction

71 K. Ramesh, 17.

72 A. Godwin, I. Ramsay, M. Webster, 236.

73 Ibid., 239. 
is advertised as one of the best ranked globally with a remarkably wellequipped international commercial court. ${ }^{74}$ When analyzing the setting in which the NCC was established, it is important to note that international trade by Dutch companies increased, but the number of commercial cases before the Dutch courts decreased. ${ }^{75}$ The reason for this trend is the fact that most contracts contained the choice of the London Commercial Court as the default forum. ${ }^{76}$ On the other hand, the main comparative advantages of the Dutch legal system are judicial independence and efficiency of the legal framework in settling disputes, including the fact that the Netherlands is an EU Member State and has concluded many bilateral treaties, which all make it easier to recognize and enforce judgments. ${ }^{77}$ The jurisdiction of the NCC is confined to civil or commercial matters in connection with a particular legal relationship within the autonomy of the parties that is not subject to the jurisdiction of the sub-district court or the exclusive jurisdiction of any other chamber or court. ${ }^{78}$ Therefore, the jurisdiction of the court does not cover all civil or commercial matters having an international element. Moreover, it is required that both parties have expressly agreed that proceedings will be in English and will be governed by the Rules of Procedure of the NCC. ${ }^{79}$ Different from the DIFCC and the SICC, all judges at the NCC are domestic Dutch judges, as required by Dutch law. ${ }^{80}$ Consequently, there is no possibility to appoint foreign judges to the Court. It can, therefore, be expected that the NCC will work on the promotion of the wider usage of Dutch procedural law by the business community as the default applicable law to resolve international commercial disputes. However, the establishment of the NCC has led to expectations that Dutch civil litigation may acquire some features of the (English) common law. ${ }^{81}$ This is the expected response to the wellestablished dominance of the London Commercial Court and English law as the applicable law in international commercial contracts. Finally, the biggest challenge to the NCC would be to break through the unjustified prejudice of the international business community regarding Dutch contract law and to make a good start. ${ }^{82}$ Regarding the good start, it is a complex task taking that there is no such thing as an easy one. The same goes for the international

\footnotetext{
74 D. Ruckteschler, T. Stooss, 433.

75 Eddy Bauw, "Commercial Litigation in Europe in Transformation: The Case of the Netherlands Commercial Court", Erasmus Law Review, Nr. 15/2019, 16.

76 Ibid.

77 Ibid.

78 Ibid., 18.

79 Ibid.

80 Ibid.

81 Ibid., 23.

82 Ibid.
} 
dispute resolution world when a new actor enters the scene - be it a new arbitral institution or an international commercial court.

\section{Influence of the International Commercial Courts on Arbitration: Partners or Competitors}

Whenever a new player enters the game, there is a question of what would be its influence on the already existing players and vice versa. There is no doubt that the resolution of international commercial disputes is a growing and very lucrative industry. It is developed as a consequence of multiple factors, but it is overall safe to say that it is a response to the international business community's need for a fast and secure system to resolve disputes. In that sense, arbitration owes its success to the fact that it provides a neutral forum. Since national forums are not considered neutral in many international instances, arbitration prevails over the national courts of the parties. Even though arbitration took international commercial disputes away from the national courts, the newly established international commercial courts turned the whole story somewhat back to where it all began. According to Middleton, arbitration's main advantages are still its privacy (confidentiality) and forum neutrality. ${ }^{83}$ In this respect, international commercial courts are somewhat comparable to arbitration. For reasons set out above, they add to its advantages and try to limit its disadvantages, thus creating a forum that can guarantee both privacy and forum neutrality, but with the convenience of court processes. ${ }^{84}$ In that fashion, nothing is taken away from the usefulness of arbitration - these new courts just offer another option of dispute resolution. Therefore, one may conclude that arbitration and international commercial courts could easily cooperate on the dispute resolution scene.

However, the great dilemma remains whether these two types of actors are competitors, or they do complement each other. As we saw earlier, these different international commercial courts are established for very different reasons. Therefore, as Bookman claims, their success and influence are to be measured by their initially envisaged role. Furthermore, Middleton contends that, as long as international commercial courts remain free from improper interference, are able to attract members of experience and quality and become known for their integrity and transparency, their popularity will grow and that will be to the advantage of international commercial community as a whole. ${ }^{85}$ Therefore, in the Singapore case, the main idea was

83 See J. Middleton.

84 Ibid.

85 Ibid. 
to establish the SICC as a one-stop-shop, where the court will be an addition to the existing arbitral institution in order to 'grow the dispute resolution pie ${ }^{86}$ Accordingly, the SICC is a cooperative new player that serves as a tool to diversify country's dispute resolution offer. It serves to those clients who would not choose international arbitration but would not be happy with national courts either. ${ }^{87}$ If we recall the NCC example, where Brexit played important role in its creation, a competition is a proper word to describe this process, but the competition is one of a special kind, that is, with the London Commercial Court, not with arbitration per se. ${ }^{88}$ Furthermore, where one adheres to the market failure rationale described above, this can be a sign of a strong competition between international commercial courts and arbitration and a notion that international commercial courts are founded on arbitration's failures. ${ }^{89}$ This does not have to be negative at all. It can be a strong impetus for a good cause for the arbitration system to improve. ${ }^{90}$ In that sense, innovative procedures introduced by the SICC are expected to be examined and followed by arbitral institutions. ${ }^{91}$

Even though most jurisdictions where international commercial courts are established are also arbitration-friendly jurisdictions, there is still a certain level of competitiveness. Dominant areas where commercial courts tend to perform better than arbitration are related to cases that are, by their nature, easier to resolve in adjudication than in arbitration. ${ }^{92}$ A good example is the web of contracts (string contracts), since the issue of multiple-party arbitration still remains unsolved..$^{93}$ Furthermore, as arbitral awards are rarely published, the adjudicatory community and international commercial law are not being developed. Such underdevelopment could change since the work of international commercial courts is generally public. ${ }^{94}$ Finally, international commercial courts can earn back the trust that has been lost for the arbitral proceedings. $^{95}$

Nevertheless, notwithstanding the main disadvantages of arbitration - costs, procedural delays and possible sanctions, powers as against third parties, confidentiality, and language as reported by Queen Mary Arbitration
86 P. Bookman (2020), 265.
87 M. Hwang, 196.
88 D. Ruckteschler, T. Stooss, 433.
89 K. Ramesh, 2.
90 D. Ruckteschler, T. Stooss, 449.
91 M. Hwang, 198.
92 D. Ruckteschler, T. Stooss, 435.
93 M. Hwang, 195.
94 Ibid., 442.
95 Ibid., 435. 
Survey - an overall conclusion is that it does not seem likely that international commercial courts would prevail over international arbitration in the near future. ${ }^{96}$ Enforceability of judgments remains a big concern alongside the fact that proceedings before these courts are in most cases state court proceedings in accordance with national rules. ${ }^{97}$ This creates uncertainty for foreign lawyers who can never be completely comfortable and familiar with procedural and substantive rules. Moreover, contrary to arbitral proceedings, home counsels will most likely be unable to represent their clients abroad before these courts. ${ }^{98}$

For Hwang, who was involved in the work of both the Supreme Court of Singapore and Dubai International Financial Centre Courts, the answer whether international commercial courts and international arbitration are competitors or partners, is that they are both. Any arbitration-friendly policy should represent a supervision with a light touch, but assistance with a strong hand. ${ }^{99}$ Therefore, the whole process of the establishment of international commercial courts comes (at least prima facie) without questioning the arbitration-friendly orientation of most jurisdictions. In that sense, in the DIFCC case, the whole first cohort of the appointed judges was composed of practicing arbitrators. ${ }^{100}$ On the competition side of the debate, it seems that both SICC and DIFCC market their services in that way to attract parties who found arbitration unsatisfactory. Moreover, both courts highlight the unrestricted subject matter jurisdiction, the ability to join third parties and a promise to resolve: the conflict of laws issues to the greatest extent possible, the over-formalization, as well as the legitimacy concerns. ${ }^{101}$ It is still questionable what the future of these courts and international commercial litigation would be. The first step of getting cases is the most exhausting, as well as creating a habit of the international business community to insert dispute resolution clauses that choose international commercial courts. Accordingly, there is always an inevitable period to wait before first disputes arise. Nevertheless, it is clear that international commercial courts, such as SICC and DIFCC, pushed the boundaries of the arbitration system. ${ }^{102}$ However, it is to be seen whether this will initiate the internal developments within the arbitration system itself. Finally, specialized international commercial courts have become a global trend, although both arbitration and domestic litigation are

\footnotetext{
96 Ibid., 449.

97 Ibid., 448.

98 Ibid., 449.

99 Ibid., 194.

100 Ibid., 195.

101 D. R. Demeter, K. M. Smith, 444.

102 Ibid., 469.
} 
still used to resolve international business disputes, these new players should prove attractive to many parties. ${ }^{103}$

\section{Conclusion}

International commercial courts are a relatively new phenomenon, yet their establishment promptly resulted in remarkable attention. Furthermore, the global business world became interested in seeing whether these new courts can be a good addition to the existing arbitration system or maybe a substitute that would better serve their needs.

In this article, the author portrayed the existing system of arbitration and argued that arbitration's negative aspects might be a starting point for these courts to emerge. Subsequently, different forces that led to the establishment of these courts were analyzed and three prominent international commercial courts were presented. Finally, the author deconstructed in which ways these courts could influence the existing arbitration system. Even though the discourse is formed in terms of cooperation versus competition, it is hard to give a straightforward answer to the question what this relationship will eventually look like. As it is shown, the most appropriate answer is currently that both cooperation and competition portray this relationship. It can be argued that these courts have the potential to become a strong competitor of the existing arbitration mechanism. Additionally, international commercial courts can be seen as a force for good that will initiate internal developments and upgrades within the arbitration system. Moreover, different international commercial courts are established with completely different ideas in mind. Therefore, their success is to be measured against these initial drivers. For all the above stated, it is too early to create any final conclusion - these courts still must develop their jurisprudence in order for academia and business community to analyze their true impact on the existing international dispute resolution environment. Before that moment, any credible assessment would be premature.

\section{References}

Ang Lance, International Commercial Courts and the Interplay Between Realism and Institutionalism: A Look at China and Singapore (Essay, Online Scholarship), Harvard International Law Journal, 2019, available at: https://harvardilj.org/2020/03/international-commercial-courts-and-

103 Damien P. Horigan, "From Abu Dhabi to Singapore: The Rise of International Commercial Courts", International Journal of Humanities and Management Sciences, Nr. 2/2015, 80. 
the-interplay-between-realism-and-institutionalism-a-look-at-chinaand-singapore/, 27. 12. 2020.

Bauw Eddy, "Commercial Litigation in Europe in Transformation: The Case of the Netherlands Commercial Court", Erasmus Law Review, Nr. $15 / 2019$.

Bookman Pamela, "New Courts, New Perspectives", Jotwell: The Journal of Things We Like (Lots), 2019, available at: https://courtslaw.jotwell.com/ new-courts-new-perspectives/, 20. 12. 2020.

Bookman Pamela K., "The Adjudication Business", The Yale Journal of International Law, Nr. 45/2020.

Chong Steven, "The Singapore International Commercial Court: A New Opening in a Forked Path", British Maritime Law Association Lecture and Dinner in London, 2015, available at: https://www.supremecourt.gov. sg/Data/Editor/Documents/J\%20Steven\%20Chong\%20Speeches/The\%20 SICC\%20-\%20A\%20New\%20Opening\%20in\%20a\%20Forked\%20 Parth\%20-\%20London\%20(21.10.15).pdf, 11. 12. 2020.

Demeter Dalma R., Smith Kayleigh M., "The Implications of International Commercial Courts on Arbitration", Journal of International Arbitration, Nr. 5/2016.

Dubinsky Paul R., "Is International Litigation a Field? Two Views of the Border", Proceedings of the ASIL Annual Meeting, Vol. 101, 2007.

Erie Matthew S., "The New Legal Hubs: The Emergent Landscape of International Commercial Dispute Resolution", Virginia Journal of International Law, Nr. 3/2019, доступно на адреси: https://poseidon01. ssrn.com/delivery.php?ID=5050740821140960180960051200031110290 49047056084030089124065094009123071127098070002052103055052 10411602309711712600707608109902804503604106501602909801600 50250240710890300270300801250900990950760950921150681180250 $67012025070116118097118105000122085 \approx E X T=p d f \mho I N D E X=T R U E$, 20. 12. 2020.

Godwin Andrew, Ramsay Ian, Webster Miranda, "International commercial courts: The Singapore experience", Melbourne Journal of International Law, Nr. 2/2017.

Horigan Damien P., "From Abu Dhabi to Singapore: The Rise of International Commercial Courts", International Journal of Humanities and Management Sciences, Nr. 2/2015.

Hwang Michael, "Commercial courts and international arbitration competitors or partners?", Arbitration International, Nr. 2/2015.

Martinez Jenny S., "Towards an international judicial system", Stanford Law Review, Nr. 56/2003. 
Middleton John, "The Rise of the International Commercial Court", The 2018 Hong Kong International Commercial Law Conference, 2018, available at: $\quad$ https://www.fedcourt.gov.au/digital-law-library/judges-speeches/ justice-middleton/middleton-j-20180921, 27. 12. 2020.

Ramesh Kannan, "International Commercial Courts: Unicorns on a Journey of a Thousand Miles", Conference on the Rise of International Commercial Courts, 2018, available at: https://www.sicc.gov.sg/docs/default-source/ modules-document/news-and-article/international-commercial-courtsunicorns_23108490-e290-422f-9da8-1e0d1e59ace5.pdf, 11. 12. 2020.

Ruckteschler Dorothee, Stooss Tanja, "International Commercial Courts: A Superior Alternative to Arbitration?", Journal of International Arbitration, Nr. 4/2019.

Sanders Pieter, "A Twenty Years' Review of the Convention on the Recognition and Enforcement of Foreign Arbitral Awards", International Lawyer, Nr. 13/1979.

Slaughter Anne-Marie, "Judicial globalization", Virginia Journal of International Law, Nr. 40/1999.

Slaughter Anne-Marie, "A global community of courts", Harvard International Law Journal, Nr. 44/2003.

Slaughter Anne-Marie, A new world order, Princeton, 2004.

Stephan Paul B., "Courts on Courts: Contracting for Engagement and Indifference in International Judicial Encounters", Virginia Law Review, Nr. 100/2014.

Whytock Christopher A., "Domestic courts and global governance", Tulane Law Review, Nr. 84/2009.

Yip Man, "The Singapore International Commercial Court: The Future of Litigation”, Erasmus Law Review, Nr. 12/2019.

Date received: 21. 2. 2021.

Date accepted: 15. 3. 2021. 